\title{
Teen financial literacy evaluated to develop outreach materials
}
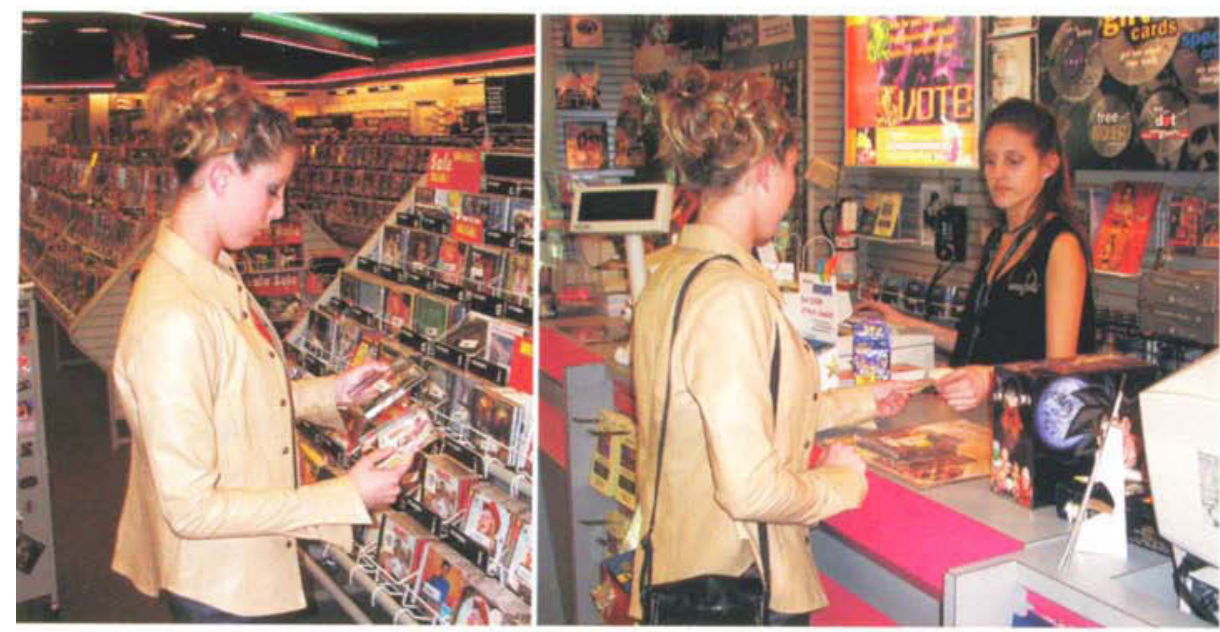

Teenagers have access to and spend a great deal of money each year, yet research indicates that their financial literacy is low. Many curricula for teaching money management exist, but we do not know if we are teaching teens what they want to know in a way that they want to learn. This study, conducted by the Money $2000+$ for Teens Workgroup of the UC Division of Agriculture and Natural Resources, sought to find out what teens want to know about financial management. Questionnaires were administered to 323 teens from five diverse groups: teens who were in juvenile hall or on probation, in public high schools, migrant education programs, pregnancy and parenting classes, and youth groups. The data were used to develop educational materials with "teen appeal," which are currently being evaluated for eventual distribution nationally.
1 Jational surveys indicate that deal of money - $\$ 155$ billion in 2000 , according to Teenage Research Unlimited (2001) - and most of that spending is related to the self-gratification of immediate wants (Sivy 1997). Their desire for goods and services motivates employment, and they often buy brands that parents view as "too expensive." A study by Alhabeeb (1996) indicated that most of adolescents' discretionary income is spent on "recreation and luxury items." Evidence that adolescents practice or appreciate saving is limited. In contrast, a more recent study by the American Savings Education Council (ASEC)(1999) found that $54 \%$ of students felt that it was important to save money on a regular basis and " $49 \%$ of students always saved some money when they received an allowance or got paid."

Does this mean that teens know how to manage their money? Not according to a recent survey. The average score for high school seniors on a national money management test was $52 \%$, a failing grade by standard grading systems (Jump\$tart Coalition 2000). In addition, their knowledge
Teenagers spend an estimated $\$ 155$ billion per year, mostly for recreation and luxury items. A study by the UC Money $2000+$ for Teens workgroup examined what kinds of outreach materials teenagers want and need for financial information. In Moreno Valley, 18-year-old Christina Craig shops at a mall for CDs.

level appears to be falling; the average score on the same test completed in 1997 was 57\% (Jump\$tart Coalition 1997).

High school seniors have little knowledge of money management, savings, investments, income and spending. Although experts contend that children can grasp the concept of money as early as age 3 (Wang 1993), the ASEC study found that the majority $(79 \%)$ of students aged 16 through 22 had never taken a class in personal finance. Two-thirds of these respondents admitted that they could use a few more lessons on money management, and $9 \%$ of the respondents were rolling over credit card debt each month (32\% had a credit card). Teenagers' spending behaviors and their limited understanding of money management can promote habits that may lead to costly mistakes today and in the future.

\section{Effectiveness of education}

A recent study of a financial planning curriculum indicated that high school students respond positively to instruction aimed at improving their money management skills (Danes et 
TABLE 1. Characteristics (\%) of teenagers surveyed about financial literacy

\begin{tabular}{|c|c|c|c|c|c|c|}
\hline & $\begin{array}{c}\text { Prb* }^{*} \\
(\mathrm{~N}=72)\end{array}$ & $\begin{array}{c}\text { Mig } \\
(\mathrm{N}=39)\end{array}$ & $\begin{array}{c}\text { Prg } \\
(\mathrm{N}=77)\end{array}$ & $\begin{array}{c}\text { Sch } \\
(N=74)\end{array}$ & $\begin{array}{c}\text { Yth } \\
(N=61)\end{array}$ & $\begin{array}{c}\text { Total } \\
(\mathrm{N}=323)\end{array}$ \\
\hline \multicolumn{7}{|l|}{ Gender } \\
\hline Male & 60 & 55 & 4 & 43 & 39 & 38 \\
\hline Female & 40 & 45 & 96 & 57 & 61 & 62 \\
\hline \multicolumn{7}{|l|}{ Grade } \\
\hline 7 th or 8 th & 9 & 0 & 0 & 25 & 15 & 10 \\
\hline 9th & 21 & 11 & 7 & 0 & 9 & 9 \\
\hline 10th & 15 & 31 & 21 & 1 & 33 & 18 \\
\hline 11 th & 22 & 19 & 37 & 10 & 22 & 23 \\
\hline 12th & 25 & 39 & 36 & 63 & 22 & 38 \\
\hline Other/not in school & 8 & 0 & 0 & 0 & 0 & 2 \\
\hline \multicolumn{7}{|l|}{ Ethnicity } \\
\hline Black & 17 & 21 & 14 & 11 & 11 & 14 \\
\hline White & 12 & 3 & 12 & 14 & 46 & 17 \\
\hline Latino & 49 & 69 & 60 & 48 & 16 & 48 \\
\hline Native Am., Eskimo, Asian, & & & & & & \\
\hline Pacific Islander, other & 23 & 8 & 15 & 27 & 28 & 21 \\
\hline
\end{tabular}

- $\mathrm{Prb}=$ juvenile hall/probation; Mig = migrant; $\mathrm{Prg}=$ pregnant/parenting; $\mathrm{Sch}=$ school; $\mathrm{Yth}=$ youth groups .

al. 1997). As little as 10 hours of classroom instruction produced significant knowledge and behavioral changes; a follow-up evaluation showed that positive changes tended to last over time. This supports findings of the Economic Research Institute that adults who grew up in states where personal finance education was mandated in high school are saving 5\% more money than their peers (Stanger 1997). Also, their net worth is higher by roughly a year's worth of earnings.

In contrast, the 2000 Jump\$tart Coalition study found that teens who had taken a financial management class did not necessarily improve their financial behavior. They were no more likely to save money or budget their income or expenditures than teens who had not taken a financial educa- tion course. Financial management education can make a difference but does not always result in positive outcomes. One reason for this difference could be whether or not the curriculum focuses on what teens want to know.

\section{Teen survey}

Because teenagers are a unique audience, identifying their interests can help to develop programs and outreach materials with "teenage appeal." In fall 1998, using a convenience sample, the Money $2000+$ for Teens Workgroup of the UC Division of Agriculture and Natural Resources (ANR) surveyed five groups of teenagers: those in juvenile halls or on probation, migrant education programs, pregnancy and parenting programs,
TABLE 2. Comparison of significant teen group responses $(\%)$ to financial literacy survey

\begin{tabular}{cccccc}
\hline \hline & $\begin{array}{c}\text { Prb* } \\
(N=72)\end{array}$ & $\begin{array}{c}\text { Mig } \\
(N=39)\end{array}$ & $\begin{array}{c}\text { Prg } \\
(N=77)\end{array}$ & $\begin{array}{c}\text { Sch } \\
(N=74)\end{array}$ & $\begin{array}{c}\text { Yth } \\
(N=61) \text { Significance }\end{array}$ \\
\hline
\end{tabular}

What makes money important to you?

(check up to three)

Buy things I need

Help my family

Do things with my friends

Buy things I want

$59 \quad 61$

$52 \quad 36$

$24 \quad 17$

Do you currently have a

(check all that apply)?

Savings account
Investments (bonds, stocks)

None of the above

93

58

77

$31 \quad 13$

57

35

35
35
44

15

41 $62 \quad P<0.001$
- $\mathrm{Prb}=$ juvenile hall/probation; $\mathrm{Mig}=$ migrant; $\mathrm{Prg}=$ pregnant/parenting; $\mathrm{Sch}=\mathrm{school} ; \mathrm{Yth}=$ youth groups .

$\dagger$ Significance of chi-square, test of independence in a $5 \times 2$ frequency. public high schools and youth groups such as $4-\mathrm{H}$.

UC Cooperative Extension advisors in Los Angeles, Imperial, San Bernardino and San Luis Obispo counties made contact with adults who worked with each of the five groups. The adults gave the surveys to the students to complete independently. The 21-question survey was kept short to encourage participants to complete it. Multiple-choice questions were used to inquire about sources of income, how teens use money, what types of financial information they would like to receive and how they would like to receive it. A total of 323 surveys were completed.

Sample characteristics. Of the teen respondents, $38 \%$ were male and $62 \%$ were female, and the majority were in 12 th grade $(38 \%)$ or 11 th grade $(23 \%)$ (table 1$)$. The largest ethnic group represented was Latino/Hispanic $(48 \%)$, followed by white $(17 \%)$ and black (14\%). The large Latino representation roughly approximates the population of Southern California, where the data was collected.

Income. Although there were variations in the amount of income, $70 \%$ reported that their parents were their main source of income - an average of $\$ 10$ a week. This was especially true for the high school and youth groups, who reported allowance and gifts as their primary sources of income. Pregnant or parenting teens primarily received income from their boyfriends and assistance programs, while the juvenile hall or probation group listed working, hustling (obtained by questionable means), selling drugs, prostitution and stealing as their sources of income. In addition, $34 \%$ of all teens received some income from odd jobs.

Use of money. When asked what makes money important to them, most of the teens indicated that it helps them to buy the things they need. This 
was especially true for $93 \%$ of pregnant or parenting teens (table 2). Second, most of the teens wanted money to help their families, which is not surprising given the survey sample. The juvenile hall and probation teens (52\%) and pregnant or parenting (58\%) youth were more likely to give this response. The teens from public high school and youth groups were more likely to indicate that money was important to them so they could do things with friends (35\% and $41 \%$, respectively) and buy things they wanted ( $35 \%$ and $62 \%$, respectively).

Interestingly, there were significant differences among the groups in whether or not they had a savings account, investments or neither. About half of teens surveyed in high school classes and those in youth groups had a savings account, as compared to only $25 \%$ of the incarcerated, $39 \%$ of migrants and $29 \%$ of pregnant or parenting teens. Only $37 \%$ of youth group and $42 \%$ of high school teens did not have a savings account or investments, while over half of the other groups did not have savings accounts or investments.

Financial information. In general, the teens wanted to know about opening and using checking and savings accounts, obtaining credit, car buying and buying clothing/personal-care items (table 3 ). The migrant (54\%) and high school $(45 \%)$ teens were interested in saving for college, while the pregnant or parenting (41\%) and juvenile hall or probation $(38 \%)$ teens were most interested in learning how to save for a home.

Not surprisingly, the teens were more interested in learning "how to get credit" than about "what credit is" and the consequences of bad debt. They wanted to learn how to deal with creditors, although the juvenile hall or probation $(25 \%)$, migrants $(27 \%)$ and public high school $(23 \%)$ teens were much more interested than pregnant

TABLE 3. What and how teens want to learn about money, comparison of teen group responses $(\%)$ to survey

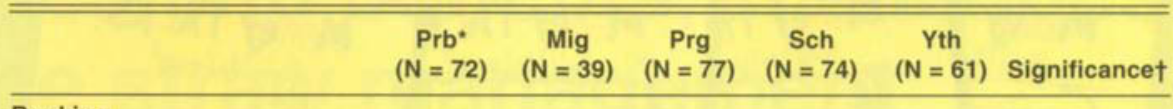

\begin{tabular}{|c|c|c|c|c|c|c|}
\hline Banking & & & & & & \\
\hline Open \& use savings account & 52 & 42 & 49 & 35 & 23 & $P<0.01$ \\
\hline Open \& use checking account & 52 & 42 & 49 & 35 & 23 & $\mathrm{P}<0.01$ \\
\hline Don't want more information & 6 & 11 & 13 & 17 & 27 & $P<0.05$ \\
\hline Saving my money & & & & & & \\
\hline Saving for college & 27 & 54 & 32 & 45 & 30 & $P<0.05$ \\
\hline Saving for a home & 38 & 30 & 41 & 22 & 15 & $P<0.01$ \\
\hline Credit & & & & & & \\
\hline Dealing with creditors & 25 & 27 & 6 & 23 & 9 & $P<0.01$ \\
\hline What is credit & 19 & 27 & 15 & 20 & 21 & NS \\
\hline How to get credit & 43 & 49 & 57 & 35 & 45 & NS \\
\hline Consequences of bad credit & 28 & 8 & 28 & 20 & 21 & NS \\
\hline How to buy & & & & & & \\
\hline Car & 74 & 62 & 68 & 65 & 61 & NS \\
\hline Clothing/personal care & 43 & 24 & 34 & 23 & 22 & NS \\
\hline $\begin{array}{l}\text { How would you like to learn } \\
\text { about the money? }\end{array}$ & & & & & & \\
\hline During school & 65 & 30 & 67 & 57 & 49 & $P<0.01$ \\
\hline Groups outside of school & 40 & 38 & 19 & 15 & 23 & $P<0.01$ \\
\hline Magazine/newsletters & 44 & 43 & 41 & 35 & 42 & NS \\
\hline
\end{tabular}

- $\mathrm{Prb}=$ juvenile hall/probation; Mig = migrant; $\mathrm{Prg}=$ pregnant/parenting; $\mathrm{Sch}=$ school; Yth = youth groups.

$\dagger$ Significance of chi-square, test of independence in a $5 \times 2$ frequency table; NS $=$ not significant.

or parenting $(6 \%)$ and youth groups $(9 \%)$. Across the groups, $14 \%$ did not want to learn about credit. Unfortunately, if not offered an extensive course in personal finance, these young people will have to learn by trial and error.

Finally, all the young people surveyed wanted to learn more about how to buy a car and clothing/personal care items. Fortunately, 35\% also realized that they need to know more about how advertising makes consumers spend.

Financial information delivery. Most of the respondents agreed that "during school" is the first choice for learning about money topics, although the migrant teens preferred to learn from organizations outside of school. Magazines and newsletters delivered to home were the second choice, followed by organizations outside of school and Web pages.

\section{Money Talks newsletters}

In response to the survey findings, the Money $2000+$ for Teens Workgroup developed a series of four attractive newsletters with corresponding leaders' guides. To improve the financial literacy of teens, we sought to find the "teach- able moment" and "teachable topic." The newsletters focus on topics identified by the teens: money personality (what influences them to spend) and spending habits, easy ways to save, shopping tips and car buying. The newsletters are designed to be hands-on and used at local schools and afterschool programs - the places where the teens said they wanted to learn. The newsletters include quizzes, informational articles and games related to a main topic such as saving or car costs.

Through a five-county pilot study, the workgroup is currently in the process of evaluating the effectiveness of these newsletters. Teens from a variety of groups including those surveyed originally are being asked questions after they use the newsletters. Based on pretest and posttest surveys, preliminary analyses indicate that they are successful in engaging and educating teenagers. For example, after being involved with the program, respondents reported talking more frequently with their families about their use of money, the importance of savings, family finances and how the family's money should be spent.

The teens also reported thinking more about saving money for the fu- 


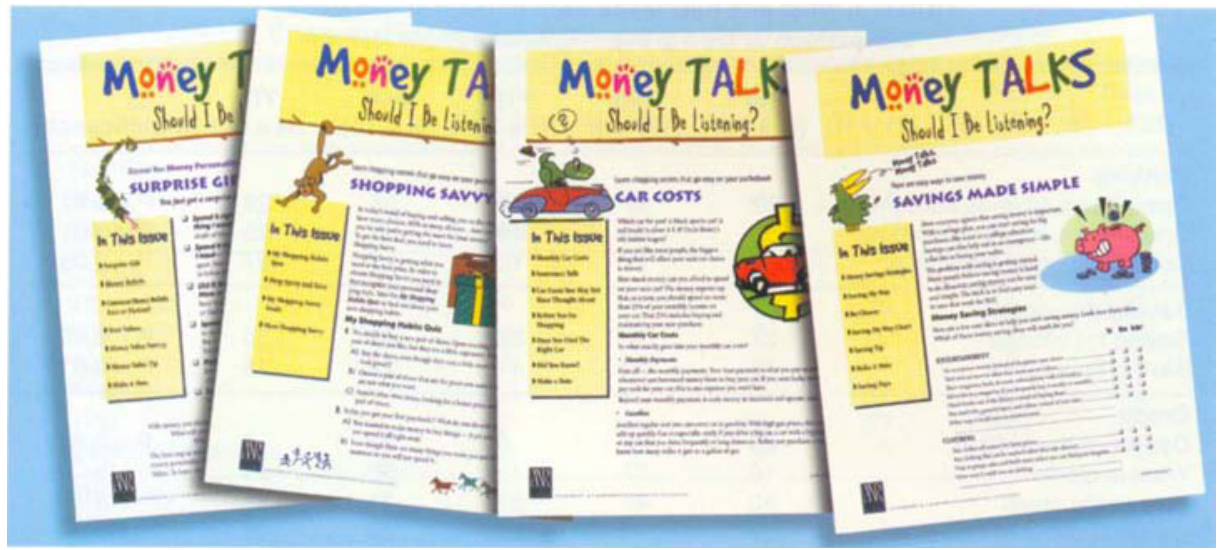

Teenagers wanted to receive information on opening checking and savings accounts, obtaining credit, buying cars, and purchasing clothing and personal care items. Based on these results, the workgroup developed four newsletters, above, which are being evaluated before national distribution. Right, Christina Craig leaves the mall.

ture, and this finding was supported by an increase in the number who saved some money weekly $(74 \%$ before versus $90 \%$ after the program). In terms of shopping, they reported comparing prices more often and waiting to buy, reducing impulse buying. The financial skills were especially relevant when it came to buying and maintaining a car. Most reported an increased awareness about ways to save money on car insurance costs, such as drivers' education, having good grades, not getting traffic tickets and being added to their parents' insurance policy.

\section{Future directions}

As a society, it is our role as educators and parents to teach youth how to develop into successful and productive adults. Inherent in this outcome is teaching youth how to successfully manage their personal finances. Through the initial survey, we learned about the extent of teens' knowledge about money and how they plan to use their money. Most importantly, we learned how teens want money management information to be presented.

After completing an evaluation of the newsletter and teacher's guide, the workgroup will revise them before distribution nationwide. The workgroup is also developing a video and Web site, which will include many of the activities from the Money Talks newsletters in an interactive format.
These will be available on compact disc for individuals and groups without Internet access. In the future, the workgroup plans to create a money management program for elementary school youth. Like reading and math, money management is a developmentally based skill, and the earlier we teach basic skills, the easier it will be for youth to learn the complexities of money management.

K. Varcoe is Consumer Education Specialist and Program Leader, Human Resources, UC Riverside; S. Peterson is Nutrition, Family and Consumer Science (NFCS) Advisor and County Director, UC Cooperative Extension (UCCE), San Luis Obispo County; C. Go is Youth Development Advisor, UCCE Alameda County; M. Johns is NFCS Advisor, UCCE Kern County; P. René-Fitch is NFCS Advisor, UCCE Imperial County; C. Powell is NFCS Advisor, UCCE Santa Barbara County; and C. Costello is Program Representative, UC Riverside. The authors wish to thank the UCCE Workgroup and Chase Manhattan Foundation for funding our work.

\section{References}

Alhabeeb MJ. 1996. Teenagers' money, discretionary spending and saving. Fin Counsel Plan 7:123-32.

American Savings Education Council. 1999. Two-thirds of American students say they need to know more about money management. News release, April 25. www.asec.org.

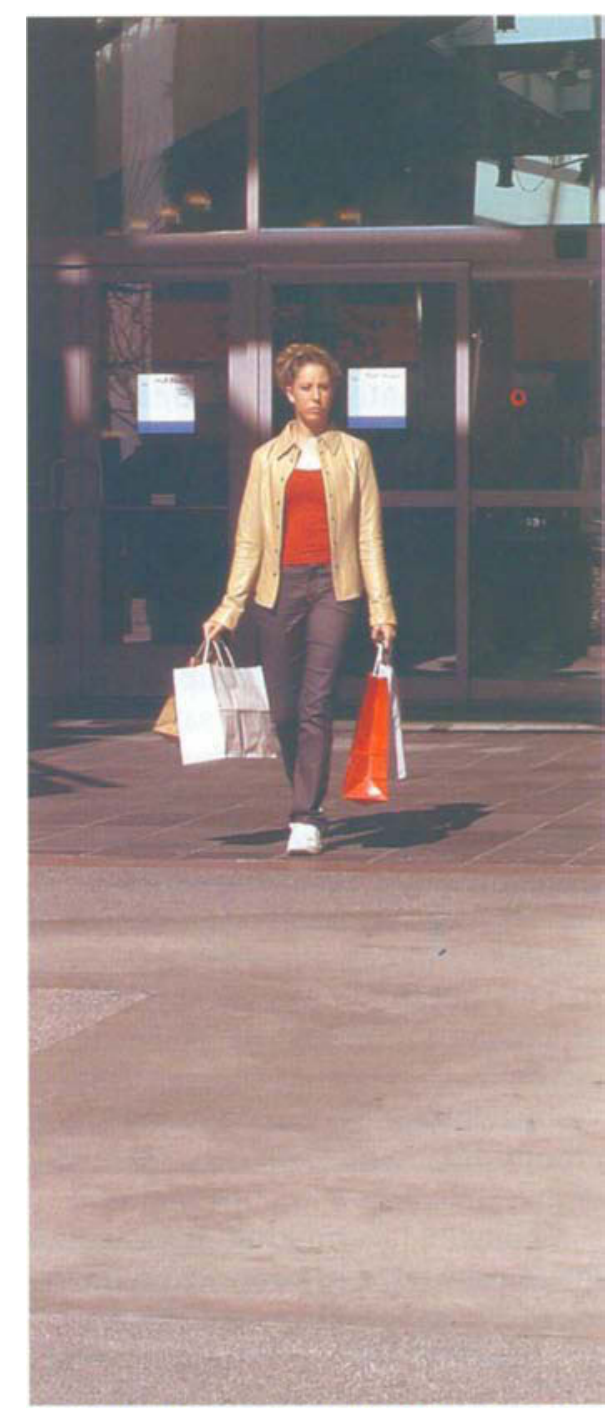

Danes S, Huddleston-Casas C, Boyce L. 1997. An evaluation of a financial planning curriculum for teens. In: Proc Assoc Financial Counseling Planning Ed 33-44.

Jump\$tart Coalition. 1997. High school seniors lack financial smarts, shows survey. News release, May 22. www.jumpstartcoalition.org.

Jump\$tart Coalition. 2000. Financial literacy declining among 12th graders. News release, April 6. www.jumpstartcoalition.org.

Sivy M. 1997. Credit card debt could be the plastic explosive that blasts the economy in '97. Money 26:180.

Stanger T. 1997. Future debtors of America. Cons Rep 62:16-9.

Teenage Research Unlimited. 2001 Teens spend $\$ 155$ billion in 2000 . News release, Jan 25. www.teenresearch.com.

Wang P. 1993. Helping your kids become financially independent. Money 22:72-8. 